\title{
CREATIVITY BASED TOURISM IN KAMPUNG KREATIF DAGO POJOK BANDUNG
}

\author{
Kresna Agung Wisesa, I Made Adhi Gunadi, Yustisia Pasfatima Mbulu \\ Fakultas Pariwisata, Universitas Pancasila Jakarta \\ Srengseng Sawah, Jagakarsa, Jakarta Selatan 12640, Indonesia
}

\begin{abstract}
In this current era, many villages in Indonesia carry the concept of Tourism Village. One of them is a creative village located in Dago Pojok Bandung, West Java. This study aims to find out about tourism products and identify how the application of creativity based tourism in the Dago Pojok creative village. Data collection is done by descriptive qualitative method with observation and interview techniques. The variables used are the concept of tourism products consisting of tourist attractions and activities, accommodation facilities and services, other facilities and services (supporting facilities), transportation facilities and services, infrastructure and other institutions, and the concept of creativity based tourism consisting of local artists, ideas/knowledge and interaction. Based on the results and discussion, it can be concluded that tourism products in Dago Pojok creative village are tourism products based on culture, creativity, and art. Dago Pojok creative village is a tourism that is based on creativity, because the elements of Local Artisan, Idea or Knowledge, and Interaction have fulfilled the requirements in implementing tourism with the concept of creativity, but there are some things that need to be improved, namely in the part of interaction it hasn't been carried out optimally.
\end{abstract}

Keyword: Creativity Based Tourism, Tourism Product, Tourism Village.

\section{PENDAHULUAN}

Industri pariwisata kini menjadi salah satu bagian terpenting bagi setiap negara, karena salah satunya adalah dapat meningkatkan suatu perekonomian suatu negara. Produk pariwisata adalah berupa jasa atau layanan. Konsumen akan mengkonsumsi produk ini dengan memperoleh pengalaman dari perjalanan yang dilakukannya. Inskeep (1991), berpendapat bahwa komponen wisata terdiri dari enam komponen diantaranya adalah atraksi dan kegiatan wisata, fasilitas dan pelayanan akomodasi, fasilitas pelayanan lainnya, fasilitas dan pelayanan transportasi, infrastruktur lainnya, kelembagaan. Pada era sekarang ini, produk pariwisata di Indonesia banyak yang megusung konsep "Desa Wisata atau "Kampung Wisata".Daya Tarik dari suatu desa atau kampung wisata merupakan kombinasi dari kegiatan sosial dan budaya masyarakatnya, dimana hal semacam ini tergambar dalam sistem adat istiadat, pola kebudayaan, kearifanlokal, kehidupan masyarakat kampung, serta aktivitas masyarakat desanya. Kota Bandung saat ini mempunyai banyak potensi pariwisatanya dan merupakan salah satu kota kreatif di Indonesia. Wakil Wali Kota Bandung Bapak Oded Danial menegaskan pada tahun 2018 akan menargetkan sekitar 7,5 juta wisatawan, angka tersebut sekitar $10 \%$ dari kunjungan wisatawan selama 2017 yang berjumlah, 6,9 juta wisatawan. Salah satu untuk memenuhi target tersebut adalah dengan cara memperbanyak jumlah Kampung atau Desa Wisata sebanyak 30 Kampung. Menurut Bapak Oded, kampung ataupun desa wisata tersebut akan dikonsep untuk menonjolkan tema tertentu serta menargetkan setiap kecamatan minimal memiliki satu kampung 
wisata. Dengan adanya program tersebut, diharapkan banyak wisatawan yang mengunjungi Kota Bandung untuk melihat industri kreatif di Bandung terutama pada kampung kreatif. Salah satunya adalah Kampung Kreatif Dago Pojok, Bandung Jawa Barat. Kampung Kreatif Dago Pojok merupakan kampung kreatif pertama yang diresmikan pada 28 Oktober tahun 2011 oleh Wakil Walikota Bandung pada saat itu yaitu Ayi Vivananda dalam upaya menciptakan konsep kota kreatif. Kampung Dago Pojok kini menjadi kampung kreatif dimana masyarakat dapat mengenal diri dan potensi untuk dapat mengembangkan permukiman yang berkelanjutan. Kampung Wisata Kreatif Dago Pojok ini dikelola oleh pemuda yang tinggal di daerah tersebut, sekitar $70 \%$, lalu orang tua dari para pemuda tersebut dijadikan sebagai penasihatnya. Dengan bermunculan program Kampung Kreatif di Bandung, menyadarkan dan menumbuhkan jiwa atau rasa kreativitas masyarakat setempat. Kini, produk wisata di Kampung Kreatif Dago Pojok ini, diantara lain ada workshop seni dan kreativitas, belajar menggambar mural, pentas seni, open trip, paket kuliner nasi liwet, souvenir, homestay, lukisan, sablon baju, cangklong patung kria, wayang, dan lain-lain. Berdasarkan latar belakang tersebut, penulis tertarik melakukan penelitian dengan judul: "Creativity Based Tourism di Kampung Kreatif Dago Pojok Bandung”.

Gambar 1.2 Bagan Kerangka Pemikiran

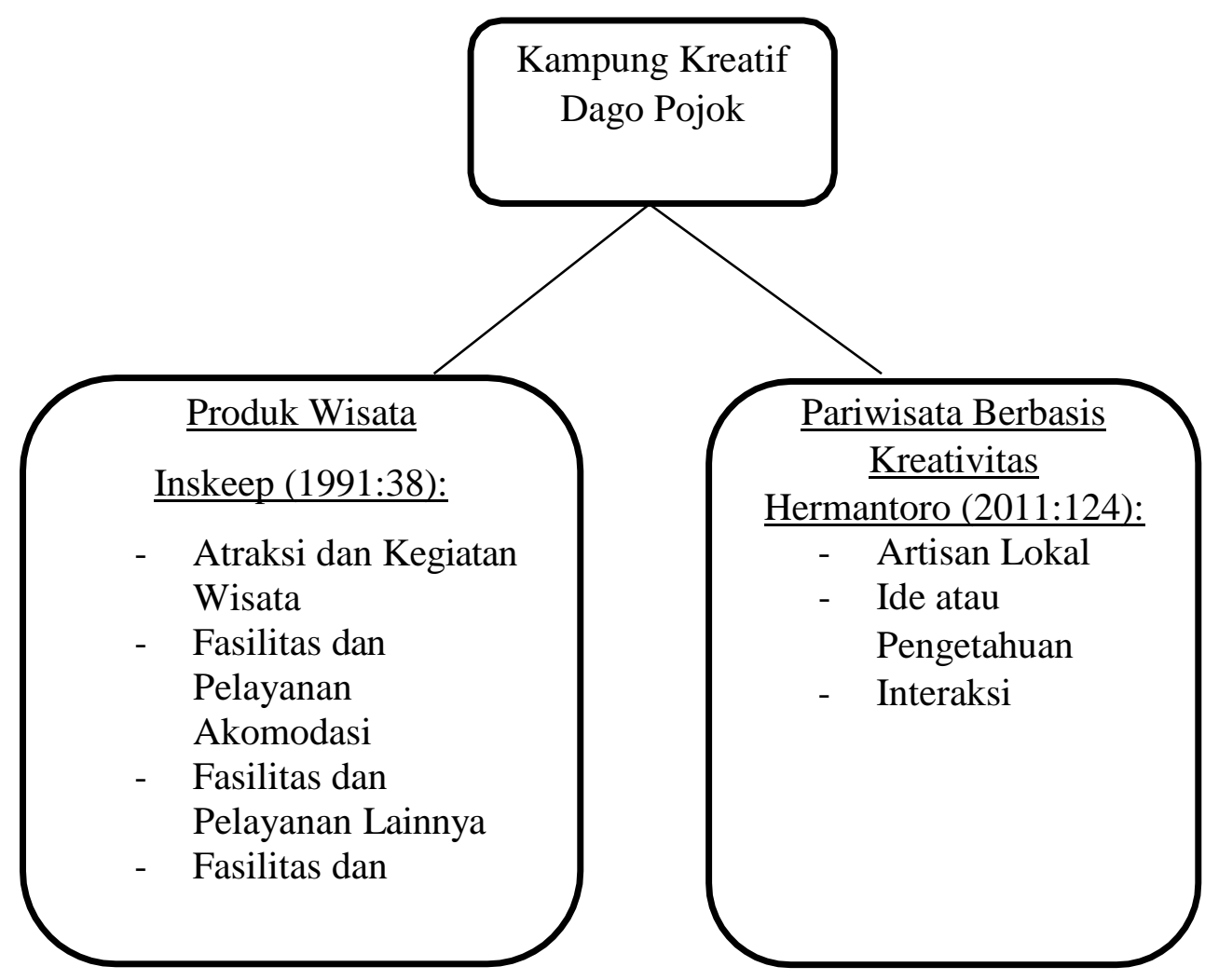




\section{RUMUSAN MASALAH}

Bagaimanakah produk wisata Kampung Kreatif Dago Pojok

- Bagaimanakah creativity based tourism di Kampung Kreatif Dago Pojok

\section{METODE PENELITIAN}

Metode penelitian yang digunakan adalah metode deskriptif kualitatif. Penelitian ini menggunakan metode tersebut dikarenakan kondisi di Kampung Dago Pojok belum banyak dikunjungi wisatawan, sehingga masih perlu banyak digali potensi-potensi dan permasalahan yang dirasakan oleh masyarakat di sana. Nazir (2003) mengungkapkan metode deskriptif sebagai: "Suatu metode dalam meneliti status kelompok, manusia, suatu objek, suatu set kondisi, suatu system pemikiran ataupun suatu kelas peristiwa pada masa sekarang. Tujuan dari penelitian deskriptif adalah untuk membuat deskripsi, gambaran atau lukisan secara sistematis, faktual, dan akurat mengenai fakta-fakta, sifat-sifat serta hubungan antara fenomena yamg diselidiki". Metode deskriptif dengan pendekatan kualitatif digunakan dalam penelitian ini untuk mendapatkan data yang lebih terperinci dan mendalam, bukan sekedar data yang telah ada.Sehingga dapat dijadikan sebuah pelajaran dan pembelajaran untuk hasil positif dan negatifnya dapat jelas terlihat. Hendarso menjelaskan bahwa penelitian kualitatif tidak dimaksudkan untuk membuat generalisasi dari hasil penelitian yang dilakukan sehingga subjek penelitian yang telah tercermin dalam fokus penelitian ditentukan secara sengaja. Subjek penelitian akan menjadi informan yang akan memberikan berbagai macam informasi yang diperlukan selama proses penelitian.

\begin{tabular}{|c|c|c|c|}
\hline Variabel & Dimensi & Indikator & Sumber \\
\hline \multirow[t]{6}{*}{$\begin{array}{l}\text { Produk Wisata } \\
\text { Inskeep } \\
(1991: 38)\end{array}$} & $\begin{array}{l}\text { Atraksi dan } \\
\text { Kegiatan } \\
\text { Wisata }\end{array}$ & $\begin{array}{l}\text { Atraksi kesenian } \\
\text { Atraksi kebudayaan } \\
\text { Atraksi buatan }\end{array}$ & $\begin{array}{c}\text { Wawancara } \\
\text { dan } \\
\text { Observasi }\end{array}$ \\
\hline & $\begin{array}{l}\text { Fasilitas dan } \\
\text { Pelayanan } \\
\text { Akomodasi }\end{array}$ & Homestay Hotel & $\begin{array}{c}\text { Wawancara } \\
\text { dan } \\
\text { Observasi }\end{array}$ \\
\hline & $\begin{array}{l}\text { Fasilitas } \\
\text { Pelayanan } \\
\text { Lainnya } \\
\text { (Penunjang) }\end{array}$ & $\begin{array}{l}\text { Tempat kuliner Toko } \\
\text { souvenir Layanan } \\
\text { informasi }\end{array}$ & $\begin{array}{c}\text { Wawancara } \\
\text { dan } \\
\text { Observasi }\end{array}$ \\
\hline & $\begin{array}{l}\text { Fasilitas dan } \\
\text { Layanan } \\
\text { Transportasi }\end{array}$ & $\begin{array}{l}\text { Angkutan umum } \\
\text { Angkutan pribadi } \\
\text { (Roda dua maupun } \\
\text { empat) } \\
\text { Tempat parker }\end{array}$ & $\begin{array}{c}\text { Wawancara } \\
\text { dan } \\
\text { Observasi }\end{array}$ \\
\hline & $\begin{array}{l}\text { Infrastruktur } \\
\text { Lain }\end{array}$ & $\begin{array}{l}\text { Toilet umum } \\
\text { Jaringan } \\
\text { listrik/telekomunikasi } \\
\text { Wifi } \\
\text { ATM }\end{array}$ & $\begin{array}{c}\text { Wawancara } \\
\text { dan } \\
\text { Observasi }\end{array}$ \\
\hline & $\begin{array}{l}\text { Kelembagaa } \\
\text { n }\end{array}$ & $\begin{array}{l}\text { Pengelola kampung } \\
\text { kreatif }\end{array}$ & $\begin{array}{c}\text { Wawancara } \\
\text { dan } \\
\text { Observasi }\end{array}$ \\
\hline \multirow[t]{3}{*}{$\begin{array}{l}\frac{\text { Creative Based }}{\text { Tourism }} \\
\text { Hermantoro } \\
(2011: 124)\end{array}$} & $\begin{array}{l}\text { Keterlibatan } \\
\text { artisan local }\end{array}$ & $\begin{array}{l}\text { 1. Artisan lokal } \\
\text { menjadi penggiat } \\
\text { kreatif } \\
\text { Artisan lokal menjadi } \\
\text { guide }\end{array}$ & $\begin{array}{c}\text { Wawancara } \\
\text { dan } \\
\text { Observasi }\end{array}$ \\
\hline & $\begin{array}{l}\text { Ide/Pengeta } \\
\text { huan }\end{array}$ & $\begin{array}{l}\text { 1. Memiliki ide } \\
\text { yang unik/menarik } \\
\text { dalam sebuah } \\
\text { atraksi wisata } \\
\text { 2. Memilki ide } \\
\text { yang } \\
\text { unik/menarik } \\
\text { dalam kegiatan } \\
\text { yang dilakukan } \\
\text { 3. Memiliki ide } \\
\text { yang unik/menarik } \\
\text { dalam membuat } \\
\text { cinderamata } \\
\text { Memiliki ide yang } \\
\text { unik/menarik dalam } \\
\text { wisata kuliner }\end{array}$ & $\begin{array}{c}\text { Wawancara } \\
\text { dan } \\
\text { Observasi }\end{array}$ \\
\hline & Interaksi & $\begin{array}{l}\text { 1. Adanya interaksi } \\
\text { antara wisatawan } \\
\text { dengan artisan lokal } \\
\text { terhadap atraksi wisata } \\
\text { 2. Adanya interaksi } \\
\text { antara wisatawan } \\
\text { dengan artisan lokal } \\
\text { terhadap kegiatan } \\
\text { wisata yang dilakukan } \\
\text { 3. Adanya interaksi } \\
\text { antara wisatawan } \\
\text { dengan artisan lokal }\end{array}$ & $\begin{array}{c}\text { Wawancara } \\
\text { dan } \\
\text { Observasi }\end{array}$ \\
\hline
\end{tabular}




\begin{tabular}{|l|l|l|}
\hline & $\begin{array}{l}\text { dalam membuat } \\
\text { cinderamata } \\
\text { Adanya interaksi } \\
\text { wisatawan dengan } \\
\text { artisan lokal dalam } \\
\text { wisata kuliner }\end{array}$ & \\
\hline
\end{tabular}

Teknik penyusunan analisis data kualitatif dalam penelitian ini antara lain:

a. Data Reduction (Reduksi Data)

b. Data Display (Penyajian Data)

c. Conclusion Drawing/Verification

Menurut Sugiyono (2017), uji keabsahan data dalam penelitian kualitatif meliputi uji credibility (validitas internal), transferability (validitas eksternal).

1. Uji Kredibilitas

Pengujian kredibilitas data atau kepercayaan terhadap data hasil penelitian kualitatif dapat dilakukan dengan cara perpanjangan pengamatan, peningkatan ketekunan dalam penelitian, triangulasi, analisis kasus negatif, menggunakan bahan referensi, dan member check.

a. Perpajangan pengamatan

Perpanjangan pengamatan artinya peneliti kembali ke lapangan, melakukan pengamatan, melakukan wawancara dengan sumber data, baik yang pernah ditemui maupun yang baru ditemui. Dengan perpanjangan pengamatan ini, hubungan peneliti dengan narasumber akan semakin terbentuk, akrab, terbuka, dan saling mempercayai, sehingga tidak ada informasi yang disembunyikan lagi.

b. Meningkatkan ketekunan

Maksudnya adalah melakukan pengamatan secara lebih cermat dan berkesinambungan. Dengan cara tersebut, kepastian data dan urutan peristiwa akan dapat direkam secara pasti dan sistematis. Meningkatkan ketekunan ibarat mengecek soal-soal atau makalah yang dikerjakan, ada yang salah atau tidak. Dengan meningkatkan ketekunan itu, peneliti dapat melakukan pengecekan kembali apakah data yang telah ditemukan tersebut salah atau tidak. Selain itu, peneliti juga dapat mendeskripsi data secara akurat dan sistematis. Triangulasi

Dalam pengujian kredibilitas, triangulasi diartikan sebagai pengecekan data dari berbagai sumber dengan bermacam cara dan beragam waktu. Dengan demikian, triangulasi terdiri atas triangulasi sumber, triangulasi teknik pengumpulan data, dan triangulasi waktu.

Triangulasi sumber dilakukan dengan cara mengecek data yang diperoleh melalui beberapa sumber. Data yang diperoleh dari beberapa sumber tersebut dideskripsikan, dikategorikan, dan akhirnya diminta kesepakatan (member check) untuk mendapatkan kesimpulan. Triangulasi teknik dilakukan dengan cara mengecek data pada sumber yang sama dengan teknik yang berbeda. Triangulasi waktu berkaitan dengan keefektifan waktu. Data yang dikumpulkan dengan teknik wawancara di pagi hari pada saat nara sumber masih segar dan belum banyak masalah akan memberikan data yang valid, sehingga lebih kredibel.

2. Pengujian Transferability

Transferability merupakan validitas eksternal dalam penelitian kualitatif. Validitas eksternal menunjukkan derajat ketepatan atau dapat diterapkannya hasil penelitian kepada populasi tempat sampel penelitian diperoleh. Nilai transfer ini berkenaan dengan pertanyaan sejauh mana hasil penelitian dapat digunakan dalam situasi yang lain. Bagi peneliti naturalistik, nilai transfer bergantung kepada pemakai.

\section{HASIL DAN PEMBAHASAN}

Kampung Kreatif Dago Pojok merupakan sebuah kampung wisata kreatif pertama yang berada di Kota Bandung, Jawa Barat. Kampung Kreatif Dago Pojok ini beralamat di Jalan Dago Pojok RT 02 RW 03, Kelurahan Dago, Kecamatan Coblong, Kota Bandung, 
Jawa Barat.Kampung Kreatif Dago Pojok ini merupakan satu RW (Rukun Warga) yang membawahi 9 RT (Rukun Tetangga). RW 03 terdiri dari RT 01 hingga RT09. Namun dalam gerakan KampungKreatif ini hanya ada 6 RT saja yangterlibat, yakni RT 01, 02, 03, 04, 07, dan

09. Guyub merupakan salah satu karakter sosial penduduk kampung Dago Pojok. Keguyuban terjadi karena hubungan kekeluargaan secara legal maupun emosional. Penghunidari Kampung Dago Pojok merupakan satu sanak keluarga antar rumah tangga satu dengan rumah tangga lainnya. Setiap generasi memiliki keturunan dan memiliki rumah yang berdekatan, terjadi pengulangan pada generasi selanjutnya dan terbentuk suatu pemukiman kampung kota.

Secara demografis, penduduk di Kampung Kreatif Dago Pojok berjumlah sekitar 3760 jiwa, jumlah tersebut terdiri dari 6 RT yang berpartisipasi kedalam Kampung Keatif Dago Pojok. 6 RT tersebut teridiri dari RT 01, RT 02, RT 03, RT 04, RT 07 dan RT 09.

Artisan lokal yang berperan pada proses pembentukan kampung kreatif dapat Pada kategori pendukung pembentukan kampung kreatif adalah Rahmat Jabaril dan Tim BCCF sebagai inisiator. Kelompok kedua adalah pendukung pembentukan kampung kreatif. Pertama, komunitas dan sukarelawan. Berasal darijejaring tim advokasi, mereka ikut serta mengembangkan ide kreatif masyarakat melalui pelatihan, workshop, dan diskusi. Kedua, swasta dan donator. Kelompok ketiga adalah masyarakat kampung kreatif itu sendiri. Kelompok ini dibagi menjadikelompok pemuda, pengurus $\mathrm{RT} / \mathrm{RW}$, dan kelompok orangtua dan anakanak.

Melihat dari teori Inskeep (1991) mengenai produk wisata, bahwa komponen wisata terdiri dari enam komponen diantaranya adalah atraksi dan kegiatan wisata, fasilitas dan pelayanan akomodasi, fasilitas pelayanan lainnya, fasilitas dan pelay anan transportasi, infrastruktur lainnya, dan kelembagaan.Atraksi dan kegiatan wisata merupakan keunikan yang ada pada sebuah destinasi wisata yang mampu menarik datangnya wisatawan. Atraksi ini dapat berupa kegiatan alam, budaya, atau pun kegiatan-kegiatan yang tidak bisa ditemui di destinasi wisata lain.

Dapat dilihat, bahwa Kampung Kreatif Dago Pojok sudah memenuhi beberapa unsur tersebut. Daya tarik wisata merupakan unsur pertama yang membentuk suatu produk pariwisata. Daya tarik wisata yang berada di Kampung Kreatif Dago Pojok merupakan daya tarik wisata yang berbasis kebudayaan, kreativitas dan kesenian, yang berkembang secara alami di kalangan masyarakat itu sendiri.Dari beberapa sumber daya tarik wisata yang teridentifikasi oleh para penggiat kreatif di kampung tersebut, bias disimpulkan bahwa ada 12 sumber daya tarik wisata yang memiliki nilai kompetitif yang unggul untuk dijadikan elemen-elemen dalam pembuatan produk pariwisata di Kampung Kreatif Dago Pojok. Meski teridentifikasi sebanyak 12 sumberdaya tarik wisata, tetapi hanya ada 6 daya tarik yang selalu menjadi produk unggulan serta paling diminati wisatawan di Kampung Kreatif Dago Pojok, yaitu seperti Jaipongan, Rampak Sekar, Celempungan, Spot foto di dinding yang digambar mural, Atraksi Hahayaman, serta Tutulan Gondang. Lalu dalam unsur terjadinya produk wisata, yang didalamnya terdapat fasilitas dan pelayanan akomodasi, fasilitas pelayanan lainnya (penunjang), fasilitas dan pelayanan transportasi, infrastruktur lain, dan kelembagaan, Kampung Kreatif Dago Pojok sudah memiliki unsur tersebut.

Hasil observasi dan wawancara yang didapatkan peneliti, bahwa para penggiat kreatif di kampung ini adalah artisan-artisan lokal di Kampung Kreatif Dago Pojok itu sendiri.Penggiat kreatif tersebut berbagai macam usia, seperti ada orang tua, pemudapemuda kampung serta anak-anak yang masih kecil yang memiliki bakat kesenian dan kerajinan yang berada di kampung ini 
karena mereka selalu belajar agar mereka peduli dengan kebudayaan Sunda dan ingin mengembangkan kampung mereka. Para orangtua ataupun penggiat kreatif ini ingin para pemuda atau anak-anak mereka di Kampung Kreatif Dago Pojok ini menjadi generasi selanjutnya untuk memajukan kampung tersebut begitupun seterusnya.

Dari penggiat kreatif ini terbagi dalam dua bagian yaitu berupa kesenian dan kerajinan. Kesenian tersebut seperti, kesenian jaipongan, pencak silat, rampak sekar, tutunggulan gondang, hahayaman dan wayang golek. Sedangkan dibagian kerajinan seperti cangklong, celempungan, sablon, seni lukis, layang-layang dan patung kriya. Selanjutnya, total artisan lokal yang menjadi penggiat kreatif \pm 20 penggiat kreatif dengan kesenian \& kerajinan yang berbeda-beda. Rata-rata para penggiat kreatif ini berumur \pm 40 tahun dengan pendidikan rata-rata adalah SMA.

Dalam ide dan pengetahuan yang dimiliki para artis-artis lokal yang diimplementasikan sebagai produk wisata Kampung Kreatif Dago Pojok, mereka memiliki kreativitas yang sangat tinggi dan unik. Unik dalam artian, produk dan kegiatan wisata yang dilakukan sangatlah berbeda dengan pariwisata-pariwisata kampung lainnya dan para pengelola kampung Kreatif Dago Pojok ingin memberikan pengalaman yang berbeda untuk wisatawan yang berkunjung dan wisatawan mempunyai kesan yang sangat sulit di dapat jika melakukan kegiatan wisata. Dalam pariwisata, keunikan merupakan sumberdaya langka yang dapat menngkatkan daya saing destinasi. Keunikan sebuah destinasi juga dapat diciptakan melalui daya kreativitasnya para artis-artis lokal.

Dari data yang didapat para artisan lokal tersebut menjelaskan, bahwa ide tersebut memang murni dari artis-artis lokal di kampung ini dan mereka ingin kampung ini dapat menginspirasi kampung-kampung lainnya di Indonesia yang mempunyai karakteristik hampir sama dengan Kampung

Kreati f Dago Pojok. Lalu, para artis-artis lokal dan juga para pemuda di kampung tersebut akan terus mengembangkan kesenian dan kebudayaan mereka agar wisatawan yang datang tidak mengalami kebosanan saat berkunjung ataupun sedang melakukan pelatihan.Kreativitas dari suatu ide dan pengetahuan sangat diperlukan untuk tetap menghidupkan sebuah destinasi pariwisata.

Interaksi yang terjadi antara wisatawan maupun artisan lokal dengan berbagai kegiatan atau aktivitas wisata yang terjadi di Kampung Kreatif Dago Pojok terkecuali dalam konteks kuliner yang masih kurang terlihat secara maksimal.Tidak sedikit wisatawan yang berkunjung hanya sekedar berkunjung saja, tetapi mereka yang datang selalu ingin ikut merasakan atraksi dan kegiatan wisata yang dilakukan, sejarah bagaiamana terjadinya sebagai kampung kreatif, nilai-nilai kebudayaannya dan unsurunsur lainnya. Hal itu pun menjadi kesan tersendiri bagi wisatawan karena mendapatkan pengalaman baru dalam melakukan perjalanan wisata. Dalam hal ini, wisatawan yang aktif melakukan interaksinya kepada para artis-artis lokal di Kampung Kreatif Dago Pojok lebih banyak dilakukan oleh wisatawan yang datang dari luar Bandung, bahkan wisatawan mancanegara pun sangat aktif melakukan interaksi dari satu masyarakat ke masyarakat lainnya. Jadi dapat dikatakan, di dalam lingkup kawasan Kampung Kreatif Dago Pojok banyak terjadi interaksi ataupun komunikasi yang dilakukan oleh wisatawan maupun masyarakat lokal.

Interaksi antara wisatawan dengan artisan lokal merupakan salah satu kegiatan yang sangat berpengaruh didalam pariwisata terutama pada pariwisata yang menerapkan konsep pariwisata pedesaan atau kampung. Hal ini terjadi karena saat terjadi interaksi, kedua belah pihak melakukan kontak untuk kegiatan pariwisata, seperti untuk pembelian paket wisata atau pemakaian kamar hotel dan penjualan suovenir. Interaksi yang berhasil mendukung lancarnya kegiatan pariwisata, begitu pula sebaliknya. 


\section{KESIMPULAN}

Produk wisata di Kampung Kreatif Dago Pojok merupakan produk wisata yang berbasis pada kebudayaan, kreativitas, dan kesenian yang berkembang secara alami dalam diri para artisan lokal. Dari dua belas jumlah atraksi dan kegiatan wisata yang tersedia, ada enam produk, Lalu dalam unsur terjadinya produk wisata, yang didalamnya terdapat fasilitas dan pelayanan akomodasi, fasilitas pelayanan lainnya (penunjang), fasilitas dan pelayanan transportasi, infrastruktur lain, dan kelembagaan, Kampung Kreatif Dago Pojok sudah memiliki unsur tersebut. Kampung Kreatif Dago Pojok merupakan pariwisata yang berbasiskan kepada kreativitas.Dengan diukur melalui konsep oleh Hermantoro (2011) dimana terdapat tiga unsur mulai dari Artisan Lokal, Ide atau Pengetahuan, dan Interaksi. Dapat dilihat semua unsur tersebut sudah terpenuhi, hanya saja ada beberapa hal yang harus lebih ditingkatkan lagi yaitu pada bagian interaksi.

\section{Daftar Pustaka}

\section{Daftar Putaska}

Ahimsa-Putra, H.S. 2004. Mengembangkan wisata budaya dan Budaya Wisata. Yogyakarta

Anandya, Dudi dan Heru, Suprihhadi. 2005. Riset Pemasaran Prospektif \& Terapan, Bayumedia Malang

Barbieri, C. and Mahoney, E., 2010. Cultural tourism behaviour and preferences among the live-performing arts audience: an application of the univorous-omnivorous framework. International Journal of Tourism Research, 12(5), pp.481-496.

Budihardjo, Eko. 1998. Kota yang Berkelanjutan (Sustainable City). UI Press: Jakarta

Butler, R.W. dan L.A. Waldbrook. 2003. A New Planning Tool: The Tourism opportunity spectrum. The Journal of
Torism Studies Vol.14, No 1

Copley, P. and Robson, I., 1996. Tourism, arts marketing and the modernist paradox.

Crosby, B. L. 1992. Stakeholder Analysis: A Vital Tool for Strategic Managers. Technical Notes, No. 2. Washington DC: Agency for International Development

Darsoprajitno, S. 2002. Ekologi Pariwisata. Penerbit Angkasa, Bandung

Douglas, P.T. Napitupulu. 2013. Perlindungan Hak Cipta Kesenian Daerah Tor-Tor Dan Gordang Sembilan (Studi di Dinas Kebudayaan dan Parawisata Provinsi Sumatera Uara). Universitas Medan Area

Dewi, M. H. U.,Fandeli, C., dna Baiquni, M. 2013. Pengembangan Desa Wisata Berbasis Partisipasi Masyarakat Lokal Di Desa Wisata Jatiluwih Tabanan, Bali. Lembaga Penelitian Universitas Udayana

Dwiputra, Roby. 2013. Preferensi Wisatawan Terhadap Sarana Wisata Di kawasan wisata Alam Erupsi Merapi. Institut Teknologi Bandung.

Evans, Graeme. et al. 2006. Strategies for Creative Spaces and Cities: Lesson Learned. London

Esterberg, Kristin G. 2002. Qualitative Methods in Social Research, New York: Mc Graw Hill.

Fandeli. 2002. Perencanaan Kepariwisataan Alam. Fakultas Kehutanan Universitas Gadjah Madah

Felsenstein, D. and Fleischer, A., 2003. Local festivals and tourism promotion: The role of public assistance and visitor expenditure. Journal of Travel Research, 41(4), pp.385-392.

Fitriyana, Freska. 2012. Peran Komunitas Kreatif Dalam Pengembangan Kota (Studi Kasus: Identifikasi Kekuatan Kolaboratif Bandung Creative City Forum $(B C C F)$. Tesis Program Studi Magister Perencanaan Wilayah dan kota. Intitut Tekonologi Bandung: Bandung

Florida, R. (2002). The Rise of Creative Class. Cambrigde: Basic Books. 
Goeldner, C. \& Ritchie, J. R. 2003. Tourism Principles Pracices and Philosophies. New Jersey: John Wiley \& Sons Hamidi. 2004. Metode Penelitian Kualitatif: Aplikasi Praktis Pembuatan Proposal

dan Laporan Penelitian. Malang: UMM Press

Hanan, Himasari. 2010. Building Creative Communities Intelligently Artepolis 2: Creative Communities and The Making of Place. Institut Tenologi Bandung

Hatch, E. and Farhady, H., 1982. Research design and statistics for applied linguistics

Hermantoro, H. 2011. Creative-Based Tourism: Dari Wisata Rekreatif Menuju Wisata Kreatif. Aditri: Cinere Depok

Hermawan, Hary. 2017. Pengaruh Daya Tarik Wisata, Keselamatan, dan Sarana Wisata terhadap Kepuasan serta Dampaknya terhadap Loyalitas Wisatawan (study comunitas Based Tourism di Gunung Api Purba Nglanggeran). Universitas sarjanawiyata Tamansiswa

Holloway, JC \& Robinson, C.. 1995. Marketing for Tourism. Longman: New YorkICOMOS. 1993. Tourism at World Heritage Sites: The Site Manager's handbook. Washington, US/ICOMOS

Indrarajasa, Susanti Widiastuti. 2011. Making a Place - Collaboration between The Developer and Creative Community in BSD City." Artepolis 3: Creative Collaboration and The Making of Place, Leraning from Creative Experience. Institute Teknologi Bandung: Bandung

Inskeep, Edward. 1991. Tourism Planning: An Integrated and Sustainable Development Approach. New York: Van Nostrand Reinhold Ireland, F., 2012. A Tourism Toolkit for Ireland's Cultural Experiences.

Ismayanti. 2010. Pengantar Pariwisata. Jakarta: PT Grasindo
Juwita, Dita. 2010. Modal Sosial yang Menjembatani dalam Pengembangan Desa Wisata Candirejo di Kecamatan Borobudur, Kabupaten Magelang. Fakultas Teknik Universitas Diponegoro

Kerlinger, F.N., 1973. Review of research in education.

Kidder, L.H., 1981. Qualitative research and quasi-experimental frameworks. Scientific inquiry and the social sciences, pp.226-256.

Kotler P., Jhon T. Bowen and James Maken. 2009. Marketing for Hospitality and Tourism 4th Edition. New Jersey: Pearson Prentice Hall

Kusyala, Dibya. 2008. Prinsip Pengembangan Kampung Kota Berdasarkan Pola Berhuni Warga. Institute Teknologi Bandung: Bandung

Landry, Charles. 2008. The Creative City: a Toolkit for Urban Innovators. Comedia

Landry, Charles dan Biancchini Franco. 1995. The Creative City. London: Demos

Landry, Charles dan Hyams Jonathan. 2012. The Creative City Index: Measuring The Pulse of The City. Comedia

McKercher, B., \& du Cros, H. 2002. Cultural Tourism: The Partnership Between Tourism and Cultural heritage Management. New York: The Haworth Hospitality Press

Mckercher, B \& du Cross. 2015. Cultural Tourism: 2nd Revised Edition. London: Taylor \& Francis Ltd

Mill,R.C and Morrison,A.M..1985. The Tourism System : An Introductory Text, Englewood Cliffs. New York: Prentice Hall,Inc

Milles, Mattew B. \& Huberman, A. Michael. 2007. Analisis Data Kualitatif. Universitas Indonesia

Nafila, Oktaniza. 2013. Peran Komunitas Kreatif dalam Pengembangan Pariwisata Budaya di Situs Megalitikum Gunung Padang Jurnal Perencanaan Wilayah dan Kota. Institut Tenologi Bandung 
Nazir, A., Mukhopadhyay, I., Saxena, D.K. and Chowdhuri, D.K., 2003. Evaluation of the no observed adverse effect level of solvent dimethyl sulfoxide in Drosophila melanogaster. Toxicology mechanisms and methods Nuryanti, W. 1999. Heritage, Tourism and Local Communities. Universitas Gajah Mada

Pearce, D. 1995. Tourism a Community Approach. Longman: New York

Permata, Ratu Selly. 2015. Peranan Industri Kreatif Terhadap Perbaikan Kondisi Sosial Budaya di Kampung Wisata Dago Pojok Kota Bandun. Universitas Pendidikan Indonesia

Pitana, I Gede. 2009. Pengantar Ilmu Pariwisata. Yogyakarta: Andi

Pitana, I Gede\& Putu, G. 2005. Sosiologi Pariwisata. Denpasar: Yayasan Andi

Priyatmono, A. F. 2012 Pengembangan Pariwisata Kreatif Berbasis Komunitas dan Budaya lokal. Universitas Muhammadiayah Surakarta

Richards, G., Wilson, J. (2007). Developing Creativity in Tourist Experiences: A solution to The Serial Reproduction of Culture? Tourism Management. England: Routledge

Richards, G., 2011. Creativity and tourism: The state of the art. Annals of tourism research,

Riduwan dan Kuncoro. 2011. Cara Menggunakan dan Memakai Path Analysis (Analisis Jalur). Bandung: Alfabeta

Rizkhi dan Buchor, Imam. 2014. Preferensi Pengunjung terhadap Daya Tarik Objek Wisata Teluk Palu di Kota Palu. Universitas Diponegoro

Rodina, Anita. 2006. Constitutional Complaint: Theory and Practice in Latvia. Summary of the PromotionThesis. Riga: Library of the University of Latvia

Satori Djam'an., Komariah Aan. 2011. Metode Penelitian Kualitatif. Alfabeta: Band ung

Sarwoko. 2007. Statistik Inferensi, C.V Andi Offset, Yogyakarta

Sharpley, Richard. 1994. Tourism, Tourists and Society. Huntingdon: Elm Publication

Soekadijo, R. G. 1997. Anatomi Pariwisata. Jakarta: Gramedia Pustaka Utama.

Sugiyono. 2017. Metode Penelitian Bisnis. Alfabeta: Bandung.

Suranti, R., 2005, July. Pariwisata Budaya dan Peran Serta Masyarakat. In Workshop Wisata Budaya Bagi Kelompok Masyarakat Propinsi DKI Jakarta (Vol. 12).

Suryadana, M. V. O. 2015. Pengantar Pemasaran Pariwisata. Alfabeta: Bandung.

Susanti, N., 2017. Upaya Greeanpeace Menjaga Kawasan Pantai Indonesia Terkait Proyek Pulau Reklamasi Teluk Jakarta. Jurnal Online Mahasiswa (JOM) Bidang Ilmu Sosial dan Ilmu Politik, 5(1), pp.1-15.

Suwarti. 2014. Pengaruh Daya Tarik Wisata Terhadap Minat Kunjungan Wisatawan Pantai Cahaya Lumba-Lumba Kendal. STIE Pariwisata

Stumpf, M.P., Thorne, T., de Silva, E., Stewart, R., An, H.J., Lappe, M. and Wiuf, C., 2008. Estimating the size of the human interactome. Proceedings of the National Academy of Sciences

Timothy, D. J., \& Nyaupane, G. P. 2009. Cultural heritage and Tourism in Developing World: A Regional Perspective.

Trigantiarsyah, R. dan Mulyadi, H. 2012. Pengembangan Produk Wisata Dengan Menggunakan Teknik Tourism Opportunity Spectrum Terhadap Keputusan Berkunjung (Survei Pada Pengunjung Cukang Taneuh/Green Canyon Kabupaten Ciamis). Manajemen Pemasaran Pariwisata FPIPS UPI

Undang-Undang Nomor 10 tahun 2009, Tetang Kepariwisataan, http://www.hukumonline.com, diakses 12 
Maret 2018

UNESCO, 2009, Panduan Dasar Pelaksanaan Ekowisata

Utami, Sekar \& Sofhani, Tubagus Furqon. 2013. Proses Pembentukan Kampung Kreatif (Studi Kasus: Kampung Dago Pojok dan Cicukang, Kota Bandung). Institut Teknologi Bandung

Yoeti, O. A. 2007. Perencanaan dan Pengembangan Pariwisata. Jakarta: PT. Pradnya

Yoeti, O. S. 1992. Penuntun Praktis Pramuwisata Profesional,

Zethani dan Bitner. 2002. Service Marketing Integrating Customer Focus Across the Firm, 3rd Edition. Boston: Mc. GrowHill/Irwin 